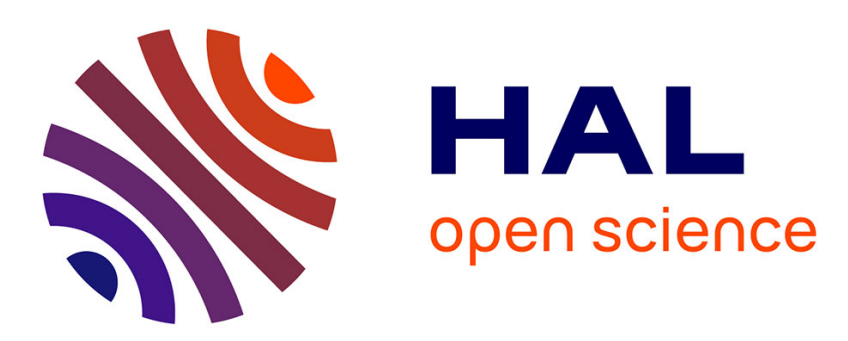

\title{
An overview of the hydraulic systems in early land plants
}

Christine Strullu-Derien, Paul Kenrick, Eric Badel, Hervé H. Cochard, Paul Tafforeau

\section{- To cite this version:}

Christine Strullu-Derien, Paul Kenrick, Eric Badel, Hervé H. Cochard, Paul Tafforeau. An overview of the hydraulic systems in early land plants. Iawa Journal, 2013, 34 (4), pp.333-351. 10.1163/2294193200000029 . hal-00964674

\section{HAL Id: hal-00964674 \\ https://hal.science/hal-00964674}

Submitted on 28 May 2020

HAL is a multi-disciplinary open access archive for the deposit and dissemination of scientific research documents, whether they are published or not. The documents may come from teaching and research institutions in France or abroad, or from public or private research centers.
L'archive ouverte pluridisciplinaire HAL, est destinée au dépôt et à la diffusion de documents scientifiques de niveau recherche, publiés ou non, émanant des établissements d'enseignement et de recherche français ou étrangers, des laboratoires publics ou privés. 


\title{
AN OVERVIEW OF THE HYDRAULIC SYSTEMS IN EARLY LAND PLANTS
}

\author{
Christine Strullu-Derrien $^{1}$, Paul Kenrick ${ }^{1}$, Eric Badel ${ }^{2,3}$, Hervé Cochard ${ }^{2,3}$ \\ and Paul Tafforeau ${ }^{4}$ \\ ${ }^{1}$ Department of Earth Sciences, The Natural History Museum, Cromwell Road, \\ London SW7 5BD, United Kingdom \\ 2INRA, UMR547 PIAF, 63100 Clermont-Ferrand, France \\ ${ }^{3}$ Clermont Université, Université Blaise Pascal, UMR547 PIAF, 63000 Clermont-Ferrand, France \\ 4European Synchrotron Radiation Facility, 6 rue Jules Horowitz, 38043 Grenoble cedex, France \\ *Corresponding author; e-mail: c.strullu-derrien@nhm.ac.uk
}

\begin{abstract}
One of the key functions of wood is hydraulic conductivity, and the general physical properties controlling this are well characterized in living plants. Modern species capture only a fraction of the known diversity of wood, which is well preserved in a fossil record that extends back over 400 million years to the origin of the vascular plants. Early fossil woods are known to differ in many key respects from woods of modern gymnosperms (e.g., tracheid size, secondary wall thickenings, lignin chemistry, cambium development) and recent discoveries are shedding new light on the earliest stages of wood evolution, raising questions about the performance of these systems and their functions. We provide an overview of the early fossil record focusing on tracheid morphology in the earliest primary and secondary xylem and on cambial development. The fossil record clearly shows that wood evolved in small stature plants prior to the evolution of a distinctive leaf-stem-root organography. The hydraulic properties of fossil woods cannot be measured directly, but with the development of mathematical models it is becoming increasingly feasible to make inferences and quantify performance, enabling comparison with modern woods. Perhaps the most difficult aspect of hydraulic conductance to quantify is the resistance of pits and other highly distinctive and unique secondary wall features in the earliest tracheids. New analytical methods, in particular X-ray synchrotron microtomography (PPC-SR $\mu \mathrm{CT}$ ), open up the possibility of creating dynamic, three-dimensional models of permineralized woods facilitating the analysis of hydraulic and biomechanical properties.
\end{abstract}

Keywords: Wood, fossil, synchrotron, 3D model, permineralization, hydraulic properties.

\section{INTRODUCTION}

The evolution of the vascular system in plants was a key development in the history of life because of its fundamental role in water transport and, in many species, its ancillary function as a framework of structural support (Sperry 2003; Pittermann 2010; Lucas 


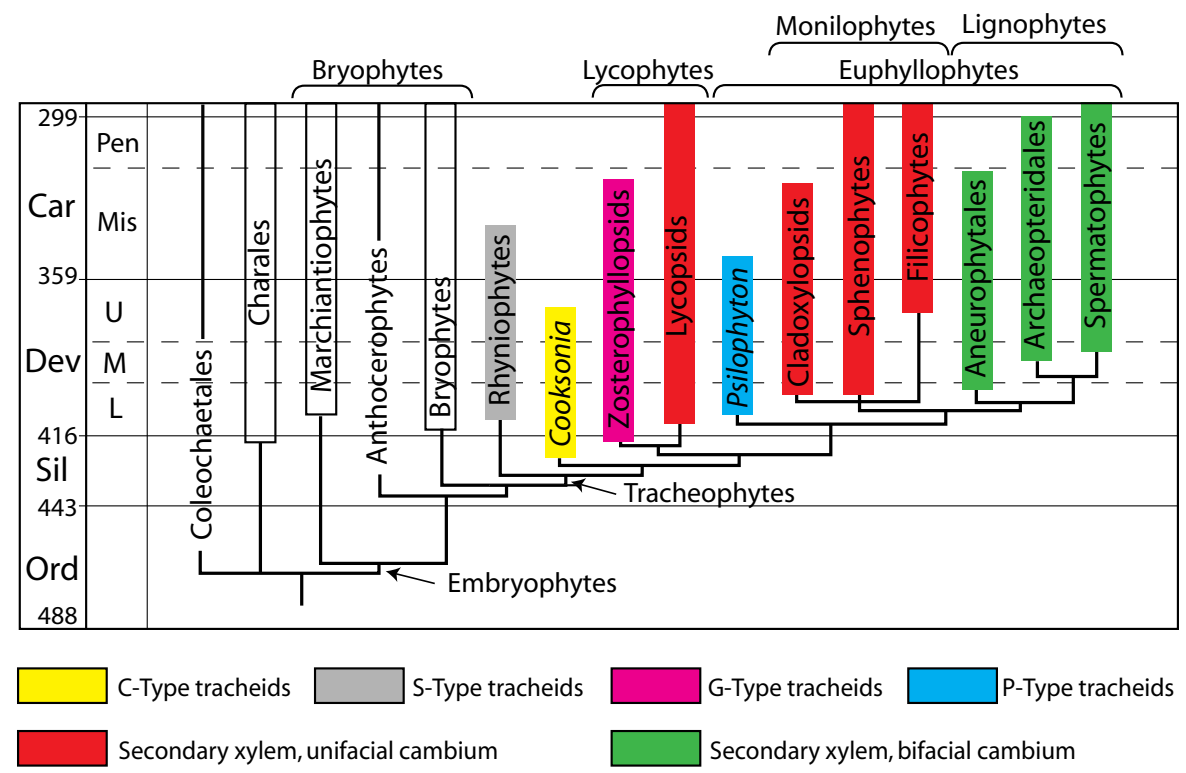

Figure 1. Simplified phylogenetic tree showing the minimum stratigraphic ranges of selected groups based on megafossils (bars) and their minimum implied range extensions (lines). Tracheid and secondary xylem types are shown on the figure. Ord = Ordovician; Sil = Silurian; Dev = Devonian, $\mathrm{L}=$ Lower, $\mathrm{M}=$ Middle, $\mathrm{U}=\mathrm{Upper} ; \mathrm{Car}=$ Carboniferous. Mis = Mississippian, $\mathrm{Pen}=$ Pennsylvanian. Adapted from Kenrick \& Crane (1997b).

et al.2013). The vascular plants or tracheophytes are defined by the possession of this tissue system, the acquisition of which was essential to the evolution of their diverse forms, leading ultimately to their dominance of terrestrial ecosystems (Niklas 1997; Bateman et al. 1998; Labandeira 2005). The constituents of the vascular system are phloem and xylem, but it is the latter that is more commonly encountered in the fossil record due to the resilience of its cellular components, which typically possess robust cell walls containing the polyphenolic polymer lignin (Boyce et al. 2004). Vascular tissues first appear in the fossil record in the lower part of the Devonian Period (410-407 Myr) (Fig. 1) when terrestrial sediments containing fossil plants first became abundant (Gensel 2008; Kenrick et al. 2012). Research over the past 25 years has revealed some of the earliest stages in the evolution of the xylem (Stein 1993) and in particular has focused on the interpretation and documentation of its main component, the tracheid (Kenrick \& Crane 1991; Edwards 1993; Friedman \& Cook 2000; Sperry 2003). Several distinctive types of tracheid are now widely recognized, providing detailed information on the structure of the cell wall and insights into the early evolution of this important cell type.

The vascular system in the earliest tracheophytes was entirely primary, but the fossil record has also provided much information on the evolution of secondary vascular tissue (Cichan 1986; Cichan \& Taylor 1990; Meyer-Berthaud et al. 2010; Spicer \& Groover 2010; Gerrienne et al. 2011). Cambial activity in plants initially evolved independ- 
ently at least twice in the Devonian Period (Kenrick \& Crane 1997a,b) and perhaps on more occasions (Boyce 2010) (Fig. 1). In many extinct groups the cambium was unifacial, developing only secondary xylem, and it was unable to undergo anticlinal cell division (Taylor et al. 2009; Spicer \& Groover 2010). This type of cambium produced the secondary xylem in the extinct tree cladoxylopsids of the Devonian Period and the lycopods and horsetails of the Carboniferous Period (Niklas 1997; Stein et al. 2007; Meyer-Berthaud et al.2010). These trees generally produced rather little wood, and the vascular cylinder had limited capacity to increase in volume while maintaining the integrity of the cambium (Cichan 1986). The more familiar bifacial cambium gives rise to both secondary xylem and secondary phloem, and it has the capacity to undergo anticlinal cell division (Donoghue 2005). This form of cambium evolved during the Devonian Period in the lineage leading to gymnosperms and angiosperms (Hilton \& Bateman 2006). New information from the early fossil record is providing further tantalizing insights that are promising to unravel the sequence of acquisition of characteristics that led to the evolution of secondary xylem (Gerrienne et al. 2011).

Our growing knowledge of the early evolution of vascular tissues derived from the careful study of fossils raises questions about the performance of these systems and their functional roles in the early development of vascular plants. Recent advances in our understanding of the hydraulics of modern woods (Hacke et al. 2004; Pittermann et al. 2006; Pittermann 2010) and the development and application of mathematical methods to infer the hydraulic properties of fossil woods (Wilson et al.2008; Wilson \& Knoll 2010; Wilson \& Fischer 2011) mean that we now have many of the tools that we need to begin to investigate the hydraulic characteristics of the earliest vascular systems in plants. Early fossil wood is typically permineralized, and various methods that have been developed to investigate and characterize its structure include the preparation of sections for light microscopy and scanning electron microscopy (Jones \& Rowe 1999). These are invasive, and they are frequently also destructive. The development of X-ray computed tomography, in particular the use of high-resolution tools such as synchrotrons, provides an efficient non-destructive alternative (e.g., Friis et al.2007). Here we give a succinct overview of the earliest fossil record of primary and secondary xylem and its cellular components and an introduction to recent research on its hydraulic properties. We show how synchrotron microtomography can be used to investigate the hydraulic properties of the earliest wood.

\section{THE EARLIEST FOSSIL EVIDENCE OF VASCULAR ELEMENTS AND THEIR HYDRAULIC STRUCTURES}

Xylem and tracheid cell structure are frequently well preserved in the fossil record enabling both biomechanical properties and hydraulic efficiency to be estimated, furthering our understanding of the functional evolution of wood (Niklas 1997; Sperry 2003; Pittermann 2010). In fossils of the early part of the Devonian period the vascular system typically is permineralized in a variety of minerals including pyrite and its oxidation products (Kenrick 1999) (Fig. 2c-e), more rarely silicates (Channing \& Edwards 2009), calcium/magnesium carbonates (Hartman \& Banks 1980), or is simply preserved as 

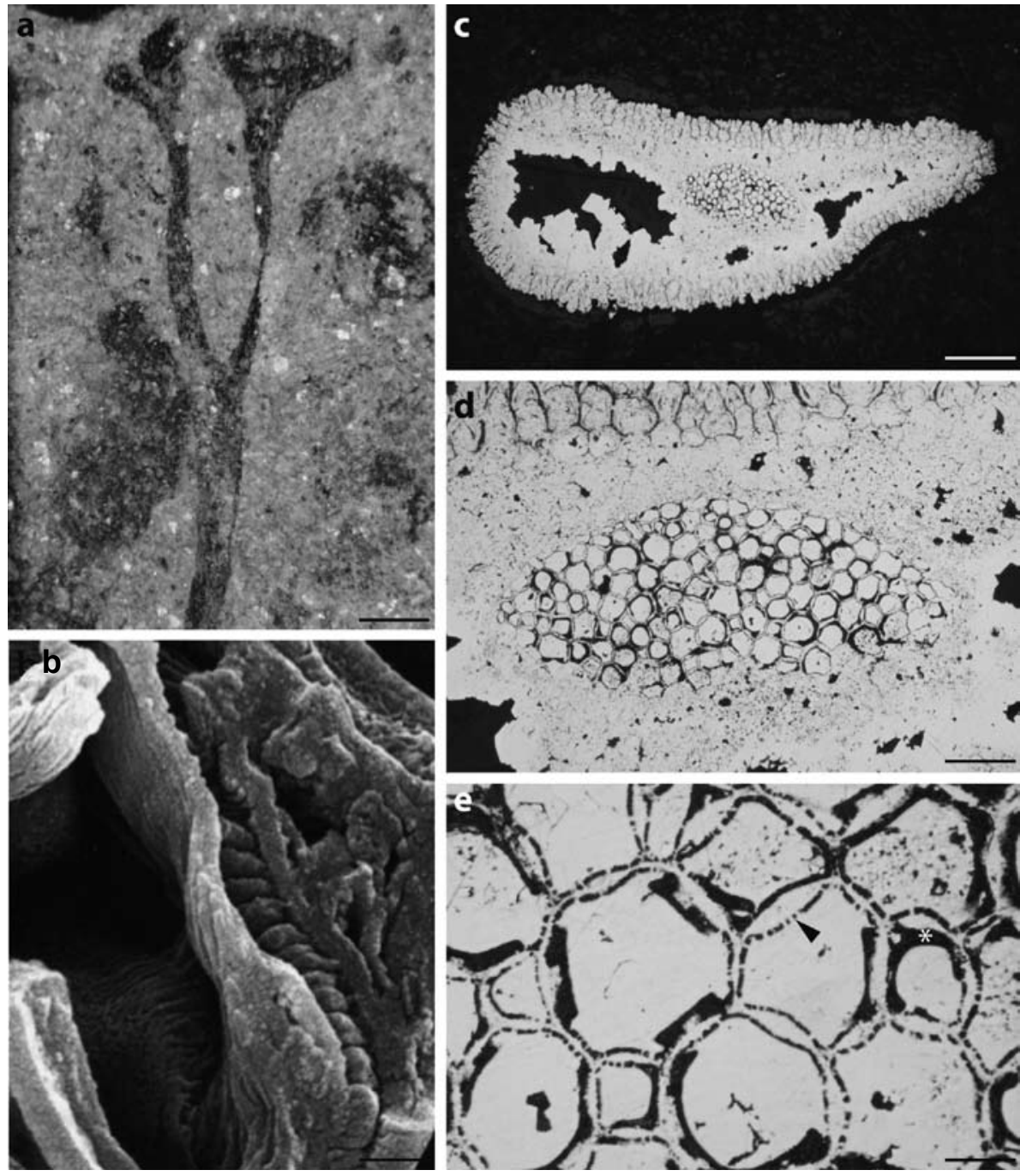

Figure 2. - a: Cooksonia pertoni: the earliest tracheophyte (Herefordshire, England; specimen nr. V 58010 Lang collection, Natural History Museum, London). Scale bar $=0.15 \mathrm{~mm}$. $-\mathbf{b}$ : Coalified tracheid in Cooksonia pertoni (C-type tracheid). Note the thick coalified wall and mineral infill of lumen with grooves marking positions of secondary thickenings (From Edwards, New Phytologist, 1993; with courtesy). Scale bar $=0.8 \mu \mathrm{m}$. $-\mathbf{c}-\mathbf{e}$ : Highly polished transverse section through a pyritized axis of Gosslingia breconensis. - c: Whole axis showing a central elliptical xylem surrounded by an amorphous acellular area of pyrite (white) and an outer cellular area. Scale bar $=250 \mu \mathrm{m} .-\mathbf{d}$ : Higher magnification of the xylem strand. Note the presence of wall pyrite between the coalified (black) walls of adjacent cells. Scale bar $=100 \mu \mathrm{m}$. $-\mathbf{e}$ : Transverse section through the cells at the edge of the xylem (G-type tracheid) showing components of the tracheid wall. Note the continuous organic wall of the annular or spiral wall sculpture $(*)$ and the broken organic wall that represents a perforate wall (arrowhead) lying between the wall thickenings. Scale bar $=25 \mu \mathrm{m}$. 
carbonized or charcoalified cells without associated mineralization (Edwards et al. 1992; Edwards 1993) (Fig. 2a, b). Interpreting cell wall structure is not straightforward, and the effects of decay and mineralization need to be critically evaluated when reconstructing tracheid characteristics and cell wall components (Kenrick \& Edwards 1988; Kenrick \& Crane 1991) (Fig. 3g-1). Some of the earliest plants possessed conducting systems comprising cells without the wall thickenings that characterize tracheids (Edwards 1993). By this we mean completely lacking helical or annular bars and pitting in the cell wall. One of the exceptionally well-preserved silicified plants from the 407-millionyear-old Rhynie Chert (Aglaophyton major) possessed a conducting system that strongly resembles the basic organization of leptoids (specialized food-conducting cells) and hydroids (specialized water-conducting cells) observed in some of the larger modern mosses (Edwards 1993), but phylogenetic analysis shows that this fossil is more closely related to the vascular plants than to bryophytes (Kenrick \& Crane 1997a, b). Tracheids may therefore have evolved from hydroid-like antecedents.

Early fossil vascular plants (Fig. 3a-f) possessed types of tracheid (Fig. 3g-1) that differ in significant ways from those of their modern relatives. One distinctive form is the S-type tracheid (Kenrick et al. 1991). This cell has large helical thickenings with a spongy interior (Fig. 3g, j). The lumen-facing surface is lined with a thin microperforate wall. Perforations within the wall measure c. $40 \mathrm{~nm}$ to $200 \mathrm{~nm}$ in diameter with a density of c. $16 \mu \mathrm{m}^{-2}$. The S-type tracheid has been observed in several stem group vascular plants (Rhynia gwynne-vaughanii, Sennicaulis hippocrepiformis, Huvenia kleui, Stockmansella sp.) (Fig. 1; 3a,d) in both their sporophyte and probably also their gametophyte generations and in two different forms of permineralization (i.e., pyrite, silicates; Kenrick \& Crane 1991). The G-type tracheid is a second distinctive form that is widespread in stem group lycopods (Fig. $1 ; 3 \mathrm{~b}, \mathrm{e}$ ). The cell is characterized by annular or helical thickenings with some cross connections (Fig. 3h, k). Typically, a distinctive perforate sheet of material occupies the cell wall between the thickenings (Kenrick \& Edwards 1988), but the thickenings themselves are known to be perforate in one species (Wang et al. 2003). Perforations in this layer are typically an order of magnitude larger than those in the S-type cell and of less regular shape (Kenrick \& Edwards 1988). The wall thickenings of both S-type and G-type cells are essentially helical or annular, but the extensive development of cross connections between bars can lead to simple reticulate pitting in the G-type cell (Kenrick \& Crane 1997a,b).

Bordered pitting developed in other tracheid types. This was an early innovation in vascular plants that evolved independently at least twice: once in lycophytes and once in euphyllophytes (Kenrick \& Crane 1997a,b). Bordered pitting characterizes the P-type tracheid, which is common to many basal euphyllophytes (Fig. 1; 3c, f). Pitting is mostly of the scalariform type, and a distinctive feature is the presence of an additional perforate sheet of wall material extending over the pit apertures (Fig. 3i, l). The perforations in this sheet are distributed either in one of two transverse rows or less regularly in a reticulum (Hartman \& Banks 1980; Kenrick \& Crane 1997a,b). Within the lycophytes, a broadly similar pit construction is seen in the fossil Minarodendron, but the scalariform bars are much more elongate (Li 1990). These are slightly different to the P-type cell. In Minarodendron, the additional perforate sheet of wall material 

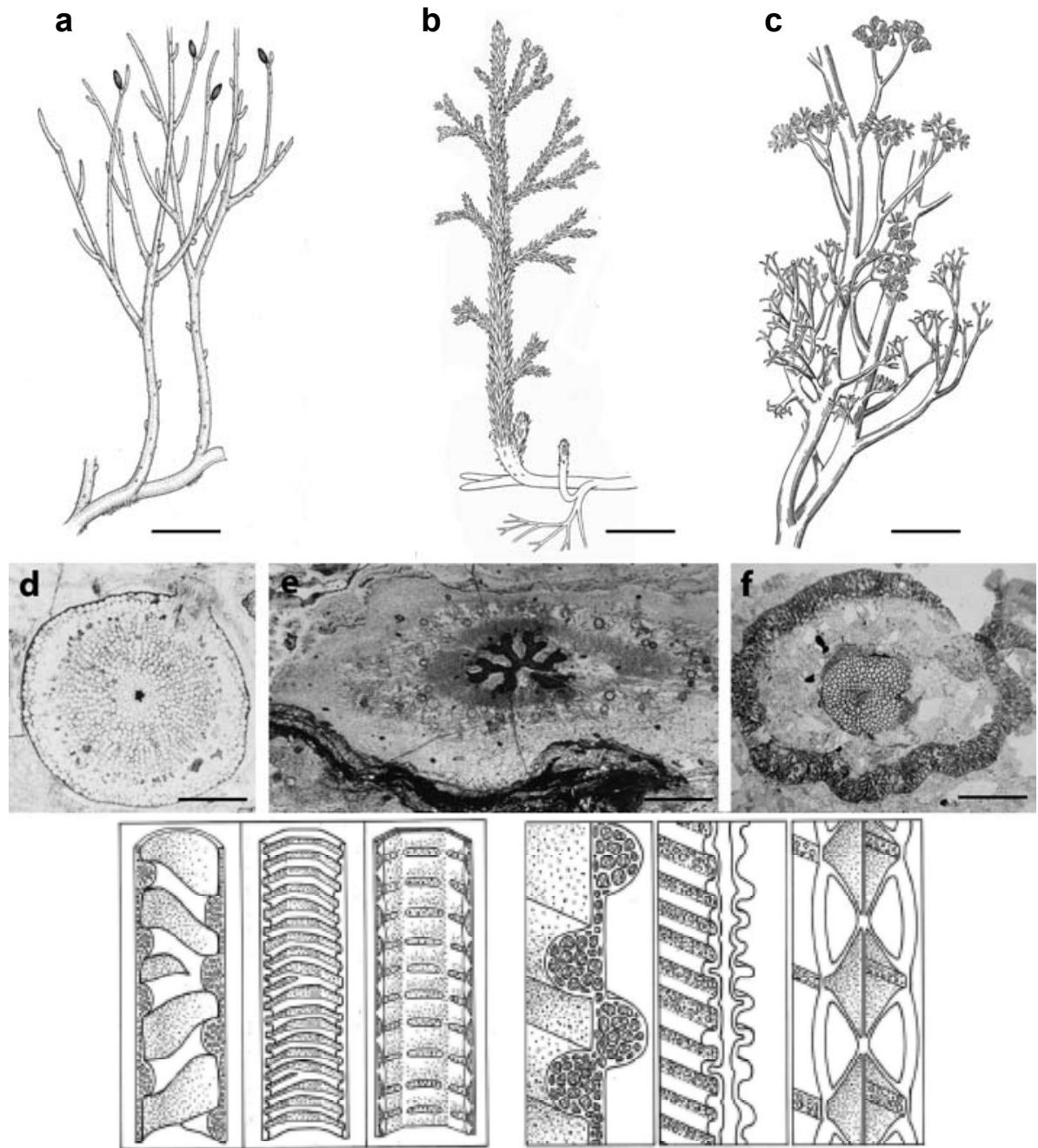

g
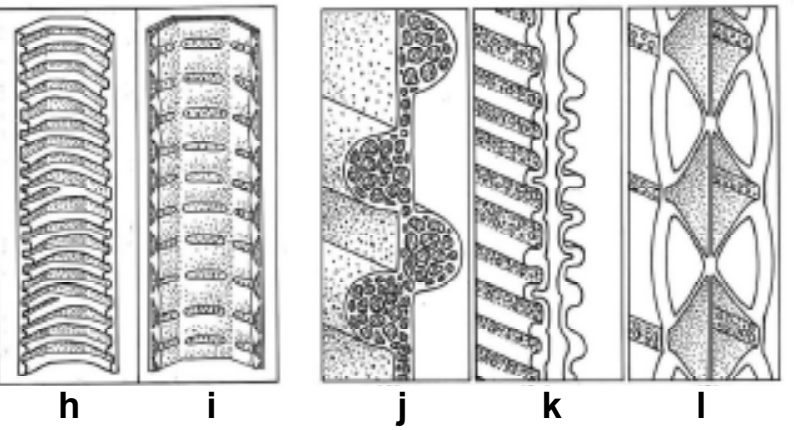

Figure 3. Early land plants and the main tracheid types. - a-c: Reconstructions of the plants. a: Rhynia gwynne-vaughanii (from Kenrick \& Crane 1997a). Scale bar $=1 \mathrm{~cm} .-\mathbf{b}$ : Asteroxylon mackiei (from Kidston \& Lang 1920). Scale bar $=1.5 \mathrm{~cm}$. - c: Psilophyton dawsonii (from Kenrick \& Crane 1997a). Scale bar $=1 \mathrm{~cm} .-\mathbf{d}-\mathbf{f}$ : Transverse sections of the axes. $-\mathbf{d}$ : Rhynia gwynne-vaughanii (slide nr. 3133, Scott collection, Natural History Museum, London). Scale bar $=0.6 \mathrm{~mm}$. $-\mathbf{e}:$ Asteroxylon mackiei (slide nr. 1015, Lang collection, Natural History Museum, London). Scale bar $=2.5 \mathrm{~mm}$. $-\mathbf{f}$ : Psilophyton dawsonii (slide $\mathrm{nr}$. OH55 x.2, Florin collection, Naturhistoriska riksmuseet, Stockholm). Scale bar $=0.6 \mathrm{~mm} .-\mathbf{g}-\mathbf{l}$ : Diversity of tracheids in early land plants (median longitudinal section through the cells, the basal and proximal end walls are not shown; cells are 20-40 $\mu \mathrm{m}$ in diameter). - g: S-type tracheid. - h: G-type tracheid. i: P-type tracheid. - j: details of S-type cell wall showing 'spongy' interior to thickenings and distribution of perforations in thin lumen-facing layer. - k: details of G-type cell wall showing perforations distributed between thickenings. $-\mathbf{l}$ : details of P-type cell wall showing pit chambers and layer with perforations that extends over pit apertures. 
is attached to the pit aperture crossing the pit chamber, whereas in the P-type cell of Psilophyton it is positioned within the pit and closer to the pit-closing membrane. This additional perforate sheet of secondary wall material associated with pitting does not occur in modern groups, and it appears to be relatively short-lived in geological terms. Within euphyllophytes and many lycopods it is soon supplanted in the Devonian Period by tracheids with more conventional bordered pits. The feature persists in some arborescent lycopods (Cichan et al. 1981) into the Carboniferous Period. The functional significance of the additional perforate sheet crossing pit chambers is unknown, but we suggest that it would have increased the hydraulic resistance of the cell wall, reducing the risk of cavitation.

The three types of early vascular element discussed above are widely recognized and have been characterized in some detail, but other variants are known to exist (e.g., C-type; Edwards 1993) (Fig. 2a, b). By the middle part of the Devonian Period tracheids with more conventional bordered pits without the additional perforate sheets of wall material had evolved (e.g., Leclercqia; Grierson 1976). In early vascular plants, the metaxylem is generally thought to be composed primarily of one or other of the main tracheid types. Thus, at any given point in a plant, the entire metaxylem would be composed of either the S-type, G-type or P-type tracheids. The assumption that one tracheid type would characterize a whole plant has recently been refuted with the discovery of G-type tracheids at one level and a pitted type at a more distal level within the same individual (Edwards et al.2006). Thus, tracheid wall structure may vary quite significantly at different levels within an individual.

The major features of the secondary walls of the earliest tracheids (i.e., presence or absence of thickenings and pitting) are distinctive and readily recognizable. One other common characteristic is the distribution pattern of organics and minerals observed within the permineralized cell walls. The significance of this needs to be interpreted carefully and with reference to the taphonomic processes involved (Kenrick \& Crane 1991). In certain forms of permineralization, notably pyrite and its oxide derivatives, the partitioning of mineral and organics (Fig. 2e) most likely reflects the distribution of resistant polyphenolics (i.e., lignin) within the basic cellulose framework of the cell wall (Kenrick \& Edwards 1988). Under this interpretation, the coalified parts of the wall are decay resistant and reflect the original pattern of lignification, whereas the mineralized parts represent areas that underwent substantial decay and are therefore likely to have been weakly lignified or non-lignified. This hypothesis has been tested through a detailed analysis of tracheid development and subsequent decay in the living lycopod Huperzia. Friedman and Cook (2000) showed that patterns of lignification in the tracheids of Huperzia broadly reflect those hypothesized in the early fossil tracheids. The fossil record shows that lignification of the cell wall in the earliest vascular plants was most well developed on the inner lumen-facing surface, but the thickness of this layer varied among cell types (Friedman \& Cook 2000). In all cells that possess this feature, the inner lumen-facing lignified layer was perforate (Fig. $3 \mathrm{j}-1$ ). The perforations were most numerous and smallest in the thin lignified wall of the S-type cell (Fig. 3j). Here, their size and distribution indicate that they might be plasmodesmata derived, because they share similarities to pores in the water-conducting cells of some living 

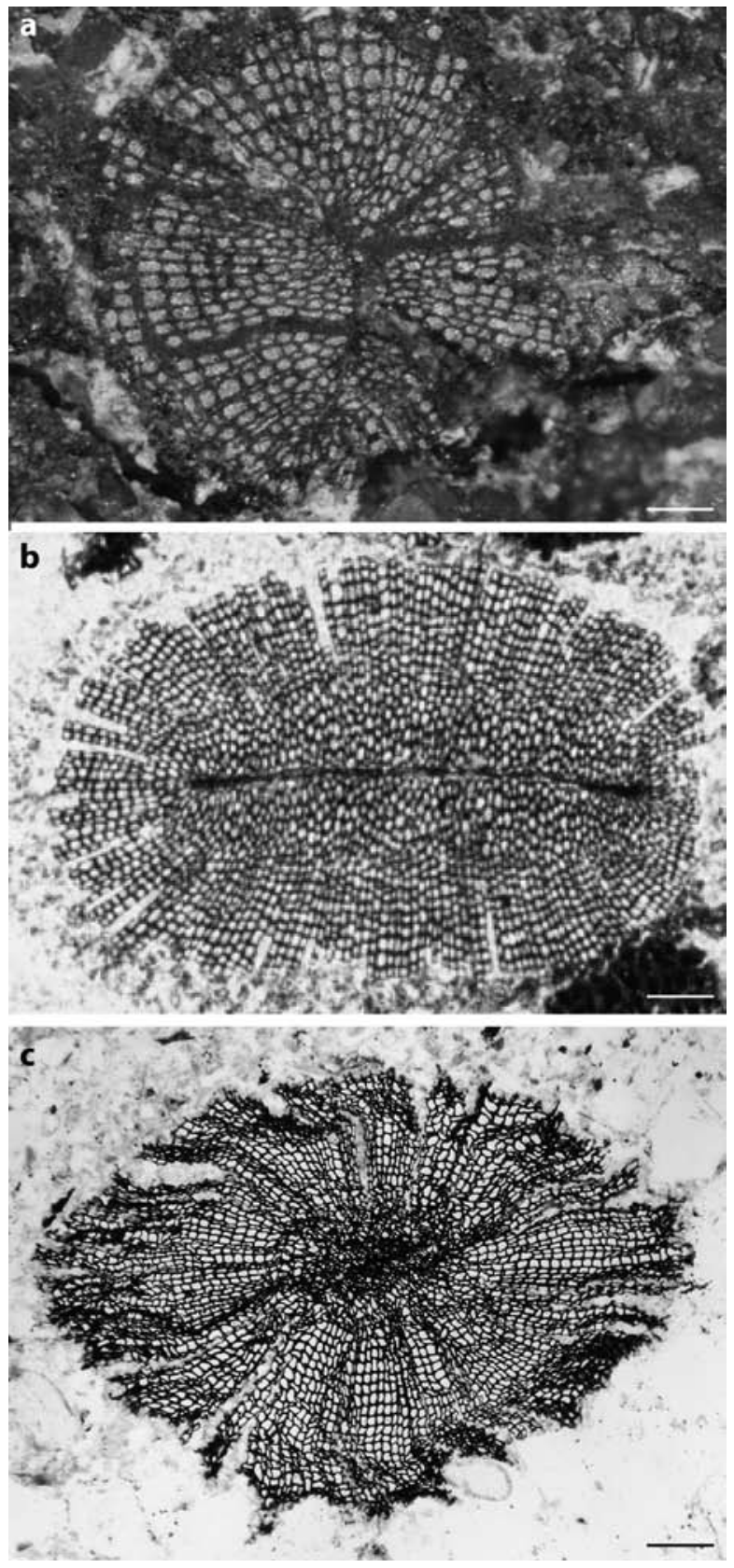

Figure 4. The three oldest (Early Devonian) euphyllophytes exhibiting wood. Transverse section of the xylem. $-\mathbf{a}$ : The plant from Châteaupanne (Armorican Massif, France). Scale bar = $200 \mu \mathrm{m}$. - b: The plant from New Brunswick (Canada) (photo P. Gensel, with courtesy). Scale bar $=300 \mu \mathrm{m}$. $-\mathbf{c}:$ Franhueberia gerrienni from Gaspé (Canada) (photo M. Tomescu, with courtesy). Scale bar $=200 \mu \mathrm{m}$. 
liverworts (e.g., Ligrone \& Duckett 1996). The perforations were larger and typically more restricted in distribution in the thicker walls of the G-type tracheids (Fig. 3k), and they reached their most developed form in the bordered pit (Fig. 31). As with bordered pits, from a functional perspective it is probable that the various forms of perforations in the walls of these early tracheids were channels enabling the flow of fluids through an otherwise impermeable wall layer.

\section{THE EARLIEST EVIDENCE OF WOOD}

The first forest ecosystems evolved by the middle part of the Devonian Period, and they were populated by arborescent plants belonging to several major lineages (Bateman et al. 1998; Gensel \& Edwards 2001; Stein et al. 2007; Gensel 2008; Meyer-Berthaud et al. 2010; Cornet et al. 2012; Stein et al. 2012; Giesen \& Berry 2013). Arborescence is known to have evolved in plants independently in many different groups, and a variety of biomechanical strategies were employed (Mosbrugger 1990; Niklas 1997; Rothwell et al. 2008; Pittermann 2010). In gymnosperms, the evolution of wood was key to the development of shrubs and trees, whereas it played a lesser role in the evolution of arborescence in several other groups of plants (Niklas 1997; Donoghue 2005; Meyer-Berthaud et al.2010). The wood of early gymnosperms was complex, derived from a bifacial cambium which, through periclinal cell division, gave rise to secondary xylem towards the centre and secondary phloem towards the outside. The secondary xylem contained both tracheids and rays. The bifacial cambium was also able to undergo anticlinal cell division to accommodate increasing girth (Niklas 1997; Spicer \& Groover 2010). Other early woods in the extinct arborescent cladoxylopsids, lycophytes and sphenophytes differed in some important features. With the possible exception of Sphenophyllum (Eggert \& Gaunt 1973; Cichan \& Taylor 1982), their cambia are generally thought to have been unifacial, producing only secondary xylem (Niklas 1997; Spicer \& Groover 2010). Furthermore, in many but not all early woody plants the cells of the unifacial cambium were unable to divide anticlinally to produce new cambial initials. Thus, the cambium in these plants had limited capacity to increase in circumference and retain its integrity as girth increased (Donoghue 2005; Spicer \& Groover 2010). Early fossils therefore show that the suite of characteristics that comprise wood in modern gymnosperms assembled over a period of time, with the capacity to produce secondary xylem appearing prior to the evolution of secondary phloem, and periclinal cell division of cambial initials appearing before the ability to sustain anticlinal divisions indefinitely. Recent research on fossils from the early part of the Devonian Period is beginning to shed further light on the earliest stages in the evolution of wood.

The earliest vascular plants possessed entirely primary growth, but among euphyllophytes one occasionally sees short files of radially aligned xylem, giving the impression of secondary growth. This was observed in Lower Devonian fossils such as Psilophyton dawsonii (Banks et al. 1975) and Psilophyton crenulatum (Doran 1980), which were leafless plants of small stature and rhizomatous growth without a well-developed root system (Fig. 3c). In their larger axes only, both plants had xylem aligned in short radial files, but there is no evidence of rays, anticlinal cell division, or secondary phloem. 
So, in these instances, it seems likely that alignment of xylem cells took place through periclinal cell divisions during primary growth.

The earliest evidence of secondary xylem in the fossil record also comes from euphyllophytes. Three occurrences have been reported recently from the Lower Devonian (Hoffman \& Tomescu 2013), but the fossils are small and fragmentary, so much remains to be learned about their overall morphology. The earliest and most complete is the plant from Châteaupanne, Armorican Massif, France (late Pragian to earliest Emsian, c. $407 \mathrm{Ma}$ ), which is thought to closely resemble Psilophyton in overall morphology and mode of branching (Strullu-Derrien et al. 2010; Gerrienne et al. 2011; Strullu-Derrien et al., submitted). Anatomical resemblances extend to the overall shape of the xylem in transverse section (Fig. 4a), the development of the primary xylem (centrarch), and the P-type tracheids (Hartman \& Banks 1980; Kenrick \& Crane 1997a,b). The plant from Châteaupanne differs from Psilophyton in the presence of secondary xylem (Gerrienne et al. 2011; Strullu-Derrien et al., submitted). The xylem cells are aligned in radial files but unlike Psilophyton there is evidence of anticlinal cell division within the cell files (Fig. $4 \mathrm{a} ; 5 \mathrm{~b}, \mathrm{c}$ ), and possibly also the remains of a cambial layer (Gerrienne et al. 2011, fig. 4E). Rays are present (Fig. 4a), and they are probably uniseriate (Strullu-Derrien et al. submitted). The rays are rare and their form and size are very variable (Gerrienne et al. 2011, fig. 1A, F, G and fig. S2, S3 Supporting online material). Another distinctive feature, common in places, is the presence of tracheids with smaller radial diameter at the periphery of the wood. This configuration of cells might indicate the presence of a growth layer boundary within the wood or near its circumference or perhaps differences in the pattern of divisions of the fusiform initials along the cambial layer. Secondary xylem was also recently reported in an unnamed fragment of plant axis from New Brunswick, Canada (Late Emsian; c. 397 Ma). The plant had a protoxylem and a metaxylem that was oval-elongate in form (Fig. 4b). The secondary xylem was composed of P-type tracheids and contained relatively numerous rays (Fig. 4b and Gerrienne et al. 2011, fig. 1D). A third taxon, Franhueberia gerriennei (Gaspé, Canada; Late Emsian; c.397 Ma) (Fig. 4c), is known from a short length of a rather distorted permineralized axis that also possessed secondary xylem of P-type tracheids. The rays are relatively numerous and they are regularly distributed (Hoffman \& Tomescu 2013). Common features that can be observed or inferred in the three earliest woody plants known include 1) presence of a cambium with both tracheid and ray initials, 2) development of secondary growth in small axes, and 3) P-type tracheids. In all three cases absence of secondary phloem in the fossilized remains of the plants could reflect either true absence or inadequate preservation, so we cannot confidently define the cambium as either unifacial or bifacial. Although these fossils are fragmentary they provide evidence for a type of or approximation of secondary growth in small stature plants prior to the evolution of a distinctive leaf-stem-root organography (Hoffman \& Tomescu 2013).

\section{ESTIMATING THE HYDRAULIC PROPERTIES OF EARLY FOSSIL XYLEM}

Our focus here is the hydraulic properties of early fossil xylem, which cannot be measured directly, but which can be estimated or modelled using approaches developed on 
living plants (Pittermann 2010). The hydraulic efficiency of xylem is proportional to the conduit diameter raised to the fourth power (Hagen-Poiseuille relation), so wide conduits are advantageous over narrow channels (Tyree \& Zimmermann 2002). The consequences of this relationship on the early evolution of xylem was first clearly demonstrated by Niklas (1985), who documented an 18-fold increase in maximum tracheid diameter during the initial diversification of vascular plants in the Devonian Period. Here, the evolution of greater hydraulic efficiency was undoubtedly related to the great increases in plant size and complexity that characterized this period of time. Using an equation derived from the Hagen-Poiseuille relation, Cichan (1986) was the first to attempt to quantify specific conductance in the secondary xylem of fossil plants with the aim of comparing values obtained to those in modern groups. Tree forms and lianas were chosen from several major extinct groups of pteridophytes (Calamitaceae, Lepidodendraceae, Sphenophyllaceae) and gymnosperms (Cordaitaceae, Medullosaceae) of the Carboniferous Period. Results indicated that conductance in some of the most ancient woody groups was comparable to that in living plants. Highly effective conducting tissues had therefore developed relatively early in plant evolution. Also of interest is that some of the general relationships between wood anatomy, growth habit, and ecology known in living plants appeared to hold for these early fossils.

Most Medullosans had an unusual and distinctive habit with slender stems that bore massive pinnately compound leaves. The vascular systems contained exceptionally wide tracheids, which is consistent with the inferred high evapotranspiration demands of the leaves (Wilson et al.2008). The remarkably high inferred conductivities of the tracheids of Lyginopteris, Callistophyton, and especially Medullosa are similar to those of some vessel-bearing angiosperms, and the vascular anatomy indicates that they played little or no structural role in supporting stems. For some species this is suggestive of a semi-self-supporting vine-like or perhaps scandent habit (Wilson \& Knoll 2010). It also indicates that these pteridosperms would not have fared well in seasonally arid or frost-prone environments, which is consistent with their inferred ecological setting as components of tropical floodplains floras (Wilson \& Knoll 2010).

The model used by Cichan (1986) treated the xylem in the stem as a single set of unobstructed pipes extending from roots to leaves and thus overestimated flow volumes through stems (Wilson et al. 2008). In other words, this simplification does not take into account the fact that tracheids have a finite length, typically in the range of about $0.5 \mathrm{~mm}$ to $4 \mathrm{~mm}$ in living conifers, and that flow between cells occurs through pits in the walls that offer significant additional resistance, reducing actual conductivity by well over $40 \%$ of that predicted by the Hagen-Poiseuille relation. Furthermore, the degree of this resistance varies with pit morphology, the porosity of the wall within the pit, and the size, number and distribution of pits, and values for this are not well characterized for living pteridophytes, many gymnosperms and their extinct relatives (Pittermann 2010). In general, we would expect the resistance of pits in the earliest fossils to be higher than those of modern plants due to the presence of an additional lignified perforate wall layer. Wilson et al (2008) took the estimation of hydraulic conductance in early vascular plants a step further by developing a model for water transport in xylem conduits that accommodated resistance to flow from pits and pit 

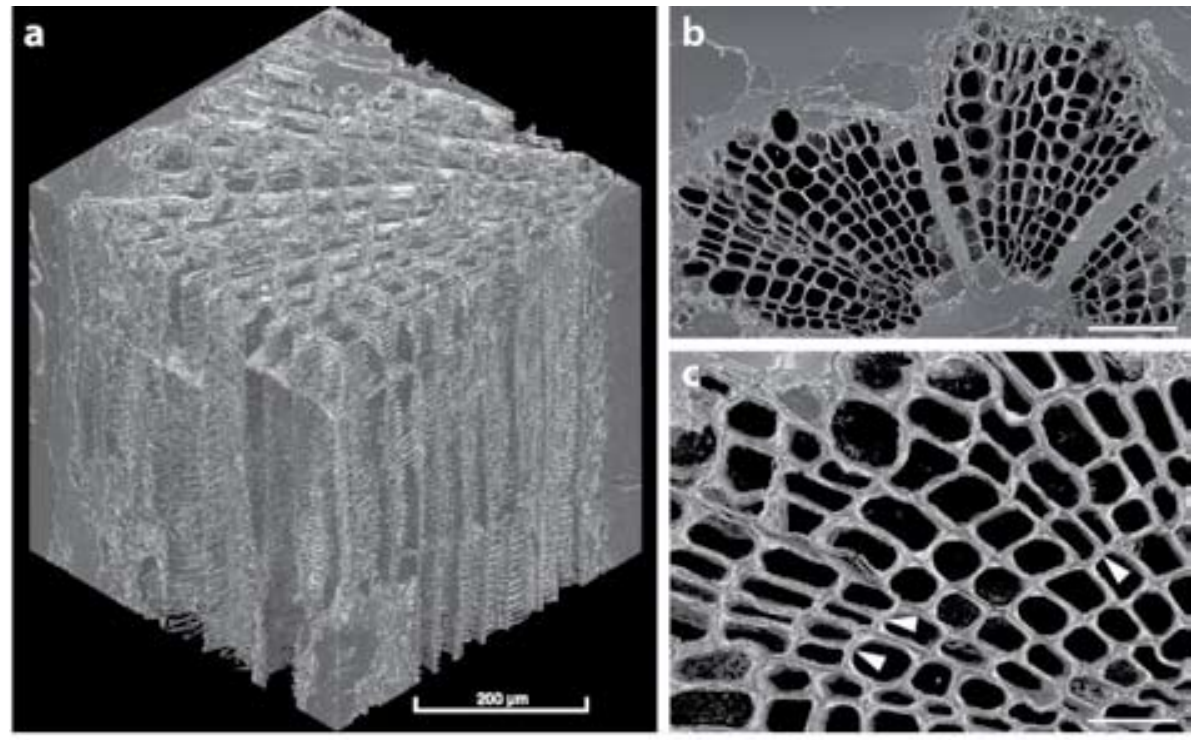

d
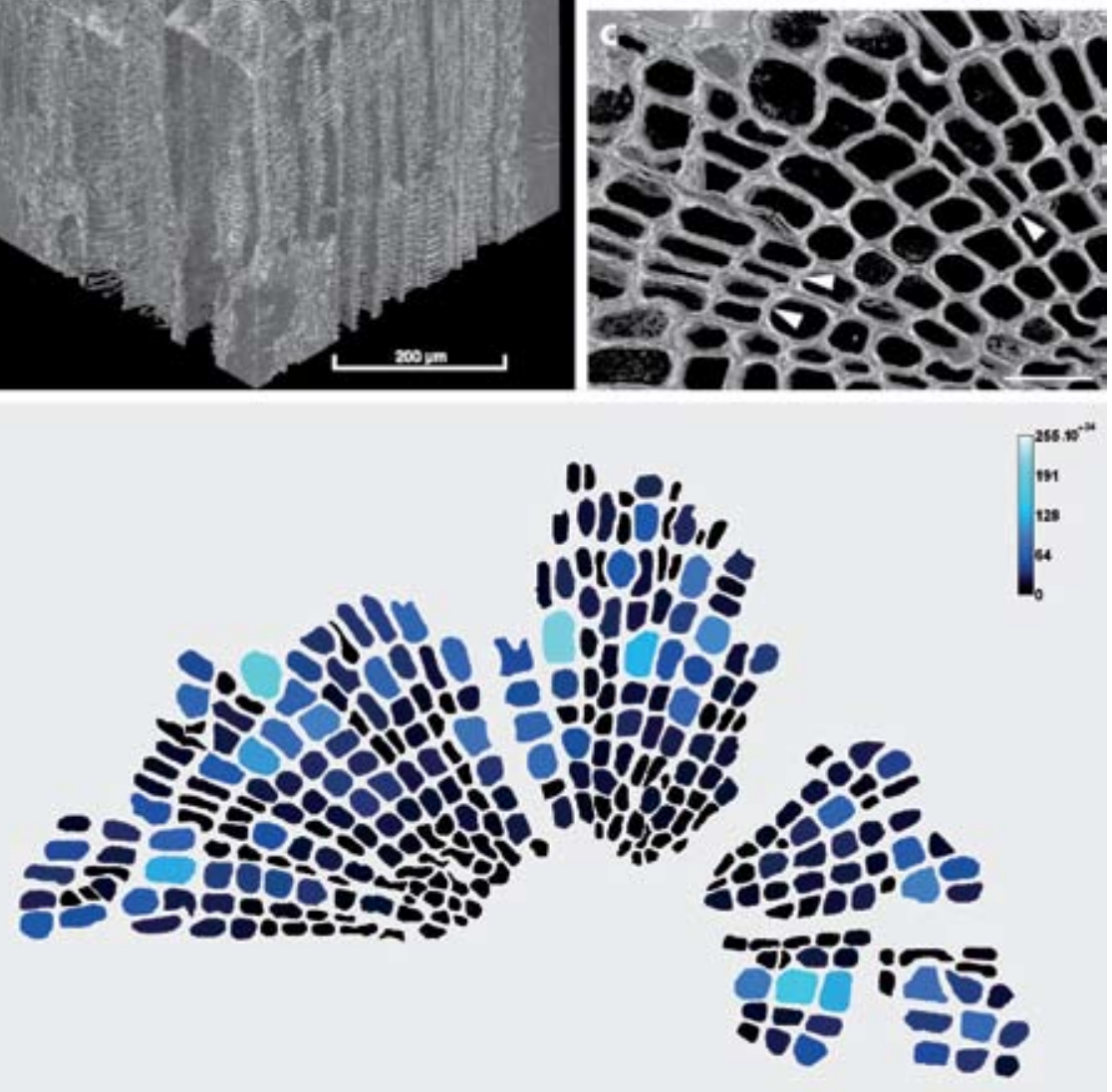

Figure 5. High-resolution Propagation Phase Contrast X-ray Synchrotron Microtomography (PPC-SR $\mu C T$ ) of 407 million year old fossil wood preserved in the mineral pyrite (FeS2) (Specimen CSD-07F-01, Université d'Angers, France). - a: Three-dimensional representation of part of pyritized axis of the plant from Châteaupanne, which has been virtually trimmed to a cubic volume. Xylem tracheids are visible in longitudinal, radial and transverse sections. - b: Transverse section extracted from the PPC-SR $\mu C T$ part of xylem embedded in shale matrix; the mineral pyrite has been virtually dissected out leaving behind the organic framework of the tracheid cell walls. Scale bar $=250 \mu \mathrm{m}$. $-\mathbf{c}$ : Higher magnification of a transverse section extracted from the PPC-SR $\mu$ CT part of xylem. At several places two xylem cell rows emanate from a single row (arrows). Scale bar $=50 \mu \mathrm{m}$. $-\mathbf{d}$ : Hagen-Poiseuille law prediction of lumens conductance based on a transverse section of part of xylem of the plant from Châteaupanne extracted from 
membranes, and they applied their model to compare hydraulic resistance in two of the extinct gymnosperms modelled by Cichan (1986) (Cordaitaceae, Medullosaceae) and living Pinus. One important distinction between the tracheids of these gymnosperms is that pit membranes in Pinus are differentiated into a torus and margo, whereas in Cordaitaceae and Medullosaceae the pit membranes are homogeneous. Also, the secondary xylem tracheids of extinct Medullosa are among the widest (commonly > $200 \mu \mathrm{m}$ ) and longest (>17.5 mm) known in seed plants (Andrews 1940). Results showed that medullosan tracheids had the capacity to transport water at flow rates more comparable to those of angiosperm vessels than to those characteristic of modern conifers and their ancient relatives (Cordaitaceae). Furthermore, results indicated that the tracheids operated at significant risk of embolism and implosion, making this plant unlikely to survive significant water stress. These observations are consistent with the general paleoecological interpretation of some medullosans as large-leaved lianas growing on tropical floodplains (DiMichele et al. 2006).

This general approach was extended recently to make a broad comparison of hydraulic conductance across seed plants, based on a sample of 22 living and extinct species (Wilson \& Knoll 2010). A morphometric approach was used comparing across groups the key factors governing hydraulic resistance: cell length, cell diameter, and pit resistance. Results showed that extinct coniferophytes fall within the range of living conifers. The efficiency of torus-margo pitting could be matched for species with homogeneous pit membranes by increasing pit area. Living cycads, extinct cycadeoids and Ginkgo overlapped with both conifers and vesselless angiosperms. However, three Palaeozoic seed plants (Lyginopteris, Callistophyton, Medullosa) stood out as occupying a unique portion of the morphospace. These extinct species therefore evolved a combination of tracheid morphologies and xylem architectures that lay outside the range observable in living gymnosperms and angiosperms.

Much less is known about the comparative hydraulics of living ferns, horsetails, lycopods and their extinct relatives. Furthermore, in stem group vascular plants, tracheids differ in significant details of wall structure (e.g., S-type, G-type, P-type) to modern forms, further complicating the modelling of their hydraulic properties. Wilson and Fischer (2011) modelled the hydraulic resistance of the tracheid cell wall of the early fossil Asteroxylon using a simple scalariform pit model. However, the tracheids in Asteroxylon are of the G-type (Kenrick \& Crane 1991); the pitting is not scalariform but basically annular developing into reticulate over part. Also, the model did not consider

PPC-SR $\mu C T$. In this section, the mineral pyrite has been virtually dissected out leaving behind the organic framework of the tracheid cell walls. The color intensity of each xylem conduit refers to its conductance performance $k_{i}$. The individual conductivities $k_{i}$ of cells were computed using the hydraulic diameter approximation that was proposed by Sisavath et al. (2001) for undefined cross sections of conduits:

$$
k_{i}=\frac{1}{32} \mu D_{H_{i}}^{2} A_{i}
$$

where $A_{i}$ is the cross-sectional area of the conduit and $D_{H_{i}}$ is its hydraulic diameter (StrulluDerrien et al., submitted). 
the effects of the presence of the additional perforate sheet of secondary wall material extending between annular bars, which significantly restricts the effective porosity of the tracheid wall. The flow from one cell to another through the wall of a G-type cell is effectively defined by the area of perforation in the secondary wall. The calculated values therefore underestimate the hydraulic resistance of this tracheid type. Despite difficulties such as these, the development of more sophisticated models incorporating pit architecture and distribution hold promise in furthering our understanding of the hydraulic properties of early wood.

In addition to the theoretical considerations of modeling hydraulic conductance outlined above, there are technical and methodological issues concerning the characterization of both primary and secondary xylem in fossil plants. One set of issues relates to the imaging and measurement of tracheid cell walls. Typically, this is done by physical preparation of permineralized fossils to make transverse, radial and tangential sections (Jones \& Rowe 1999). Measurements and imaging of tracheids would involve light microscopy. The method is destructive (i.e., results in loss of materials) and usually the number of preparations that one can make is rather limited. Scanning electron microscopy is used typically to develop detailed reconstructions of pit structure. Recently we showed how Synchotron microtomography can be used to document the structure of the earliest wood and to collect measurements to perform calculations on hydraulic conductivity (Fig. 5a-d and Strullu-Derrien et al. submitted).

\section{THE POTENTIAL OF SYNCHROTRON MICROTOMOGRAPHY}

Synchotron microtomography (Feist et al. 2005; Lak et al. 2008; Tafforeau \& Smith 2008) provides a new approach to investigating the structure and the hydraulic properties of early fossil wood (Strullu-Derrien et al., submitted). The method is (i) noninvasive and non-destructive, (ii) enables the visualization of wood volumes in three dimensions, and (iii) allows dynamic virtual dissection in any number of transverse, radial, and tangential sections to explore properties at the cellular level (Fig. 5a). For example, we were able to trace rays through a block of xylem and visualize in longitudinal tangential section the interface with xylem tracheids and rays. Adjacent tracheids have a double wall (consisting of the secondary walls of each tracheid whereas the interface with the ray shows only a single wall (tracheid wall) as cells within the ray are not preserved (Strullu-Derrien et al., submitted). Also virtual 3D histological sections (Fig. 5b,c) were generated from the reconstructed 3D volume, and used to estimate the hydraulic conductivity. Shape parameters $\left(A_{I}\right.$ and $\left.p_{i}\right)$ of the cell lumens were measured in transverse section using the ImageJ software (Rasband 2012) (Fig 5d) (Strullu-Derrien et al., submitted).

With standard paleobotanical methods, such observation and measurement require sectioning in three orientations (transverse, radial and tangential) and the using of etching agents, and they are destructive. Much early fossil wood is permineralized in pyrite $\left(\mathrm{FeS}_{2}\right)$, which may become partially or completely oxidized (Kenrick 1999). The permineralization process results in mineralization that is believed to reflect the distribution of decay-resistant organics (i.e., lignin) within the original cellulose matrix 
of the cell wall (Kenrick \& Crane 1991; Edwards 1993). Synchrotron microtomography makes possible the virtual removal of the mineral to reveal the coalified remains of the cell walls, thereby eliminating the need for chemical etching (Fig. 5b, c). Imaging is based on the attenuation of X-rays as they pass through the object, which is related to its density and chemical composition. It is possible that this approach would also work for woods preserved in other common minerals, including calcium, magnesium, and iron carbonates, and silicates. Tomography is dependent on density contrasts and it has to be noted that results that are very informative for fossils preserved in pyrite may be less so for fossils permineralized in calcite and silica. The method will probably be most effective where mineral replacement of the organic remains of the cell walls is incomplete. The volume of wood we reconstructed is small (Fig 5a), but in principle larger volumes can be imaged, allowing the accurate measurement of tracheid length and also an assessment of the distribution and density of pits within tracheid cell walls; however, there is going to be a trade-off between volume imaged and resolution. Larger volumes generally result in lower resolution. Our results show that the method works for early wood preserved in pyrite; it enables the dynamic 3D imaging of the wood, and it facilitates the analysis of its hydraulic and biomechanical properties in a non-invasive and non-destructive way.

\section{CONCLUSION}

Understanding the early evolution of hydraulic conductivity in wood requires a detailed documentation of early fossils. The xylem in fossils is often well-preserved providing information on the structure of the tracheids and the general form and composition of the vascular system. Recent studies show that early fossil woods differ in many key respects to those of modern gymnosperms (e.g., tracheid size, secondary wall thickenings, lignin chemistry, cambium development).

Hydraulic conductivity cannot be measured directly in fossils, but estimates can be obtained by measuring various properties of the fossilized water-conducting cells and using these as values in increasingly sophisticated biophysical models. This approach holds great promise in furthering our understanding of the hydraulic properties of early wood however modelling pit resistance in early fossils remains challenging.

Synchrotron microtomography is a flexible new and non-invasive tool for the study of permineralized woods that enables their dynamic virtual dissection. The method is effective for woods preserved in pyrite $\left(\mathrm{FeS}_{2}\right)$, and might also prove effective for woods preserved in other common minerals. The method facilitates the collection of measurements needed to calculate hydraulic conductivity, in a non-destructive way and for very small samples, which is a clear advantage.

The fossil record shows that wood evolved in small stature plants prior to the evolution of a distinctive leaf-stem-root organography. It also demonstrates that the suite of characteristics that comprise wood in modern gymnosperms assembled over a period of time. Results are beginning to show combinations of features in fossil woods that are outside of the range observed in modern plants. Knowledge of the hydraulic and the biomechanical properties of fossils woods can also help inform on the growth habit and ecology of extinct plants. 


\section{ACKNOWLEDGEMENTS}

The authors thank Pieter Baas and Elisabeth Wheeler, Editors-in-Chief of the IAWA Journal for their invitation to write this article. They thank Dianne Edwards, Patricia G. Gensel and Alexandru M. Tomescu for permission to reproduce figures. C.S-D received financial support from the European Commission under the Marie Curie Intra-European Fellowship Programme FP7-People-2011-SYMBIONTS.

\section{REFERENCES}

Andrews HN. 1940. On the stelar anatomy of the pteridosperms with particular reference to the secondary wood. Ann. Missouri Bot. Gard. 27: 51-118.

Banks HP, Leclercq S \& Hueber FM. 1975. Anatomy and morphology of Psilophyton dawsonii, sp.n. from the late Lower Devonian of Quebec (Gaspé), and Ontario, Canada. Palaeontograph. Amer. 48: 77-127.

Bateman RM, Crane PR, DiMichele WA, Kenrick P, Rowe NP, Speck T \& Stein W. 1998. Early evolution of land plants: phylogeny, physiology, and ecology of the primary terrestrial radiation. Ann. Rev. Ecol. Syst. 29: 263-292.

Boyce CK. 2010. The evolution of plant development in a paleontological context. Curr. Opin. Pl. Bio. 13: 102-107.

Boyce CK, Zwieniecki MA, Cody GD, Jacobsen C, Wirick S, Knoll AH \& Holbrook NM. 2004. Evolution of xylem lignification and hydrogel transport regulation. Proc. Natl Acad. Sci. USA 101: 17555-17558.

Channing A \& Edwards D. 2009. Silicification of higher plants in geothermally influenced wetlands: Yellowstone as a Lower Devonian Rhynie analog. Palaios 24: 505-521.

Cichan MA. 1986. Conductance in the wood of selected Carboniferous plants. Paleobiol. 12: 302-310.

Cichan MA \& Taylor TN. 1982. Vascular cambium development in Sphenophyllum: a Carboniferous arthrophyte. IAWA Bull. n.s. 3: 155-160.

Cichan MA \& Taylor TN. 1990. Evolution of cambium in geologic time - a reappraisal. In: Iqbal M (ed.), The vascular cambium: 213-221. John Wiley \& Sons, New York.

Cichan MA, Taylor TN \& Smoot EL. 1981. The application of scanning electron microscopy in the characterization of Carboniferous lycopod wood. Scan. Elect. Microsc. 3: 197-201.

Cornet L, Gerrienne P, Meyer-Berthaud B \& Prestianni C. 2012. A Middle Devonian Callixylon (Archaeopteridales) from Ronquières, Belgium. Rev. Palaeobot. Palynol. 183: 1-8.

DiMichele WA, Phillips TL \& Pfefferkorn HW. 2006. Paleoecology of Late Paleozoic pteridosperms from tropical Euramerica. J. Torrey Bot. Soc. 133: 83-118.

Donoghue MJ. 2005. Key innovations, convergence, and success: macroevolutionary lessons from plant phylogeny. Paleobiol. 31: 77-93.

Doran JB. 1980. A new species of Psilophyton from the Lower Devonian of northern New Brunswick, Canada. Can. J. Bot. 58: 2241-2262.

Edwards D. 1993. Cells and tissues in the vegetative sporophytes of early land plants. New Phytol. 125: 225-247.

Edwards D, Davies KL \& Axe L. 1992. A vascular conducting strand in the early land plant Cooksonia. Nature 357: 683-685.

Edwards D, Li CS \& Raven JA. 2006. Tracheids in an early vascular plant: a tale of two branches. Bot. J. Linn. Soc. 150: 115-130.

Eggert DA \& Gaunt DD. 1973. Phloem of Sphenophyllum. Amer. J. Bot. 60: 755-770.

Feist M, Liu J \& Tafforeau P. 2005. New insights into Paleozoic charophyte morphology and phylogeny. Amer. J. Bot. 92: 1152-1160. 
Friedman WE \& Cook ME. 2000. The origin and early evolution of tracheids in vascular plants: integration of palaeobotanical and neobotanical data. Phil. Trans. Roy. Soc. London B355: 857-868.

Friis EM, Crane P, Pedersen KR, Bengston S, Donoghue PCJ, Grimm GW \& Stampanoni M. 2007. Phase-contrast X-ray microtomography links Cretaceous seeds with Gnetales and Benettitales. Nature 450: 549-552.

Gensel PG. 2008. The earliest land plants. Ann. Rev. Ecol. Syst. 39: 459-477.

Gensel PG \& Edwards D. 2001. Plants invade the land: evolutionary and environmental perspectives. Critical Moments and Perspectives in Earth History and Paleobiology Series. Columbia University Press, New York.

Gerrienne P, Gensel PG, Strullu-Derrien C, Lardeux H, Steemans P \& Prestiani C. 2011. A simple type of wood in two Early Devonian plants. Science 333 (6044): 837.

Giesen P \& Berry CM. 2013. Reconstruction and growth of the early tree Calamophyton (Pseudosporochnales, Cladoxylopsida) based on exceptionnally complete specimens from Lindlar, Germany (mid-Devonian): organic connection of Calamophyton branches and Duisbergia trunks. Int. J. Plant Sci. 174: 665-686.

Grierson JD. 1976. Leclercqia complexa (Lycopsida, Middle Devonian): its anatomy, and the interpretation of pyrite petrifactions. Amer. J. Bot. 63: 1184-1202.

Hacke UG, Sperry JS \& Pittermann J. 2004. Analysis of circular bordered pit function. II. Gymnosperm tracheids with torus-margo pit membranes. Amer. J. Bot. 91: 386-400.

Hartman CM \& Banks HP. 1980. Pitting in Psilophyton dawsonii, an early Devonian trimerophyte. Amer. J. Bot. 67: 400-412.

Hilton J \& Bateman RM. 2006. Pteridosperms are the backbone of seed-plant phylogeny. J. Torrey Bot. Soc. 133: 119-168.

Hoffman LA \& Tomescu AMF. 2013. An early origin of secondary growth: Franhueberia gerriennei gen. et sp. nov. from the Lower Devonian of Gaspé (Quebec, Canada). Amer. J. Bot. 100: 754-763.

Jones TP \& Rowe NP. 1999. Fossil plants and spores: modern techniques. The Geological Society, London. 396 pp.

Kenrick P. 1999. Opaque petrifaction techniques. In: Jones TP \& Rowe NP (eds.), Fossil plants and spores: modern techniques: 8-91. The Geological Society, London.

Kenrick P \& Crane PR 1991. Water-conducting cells in early fossil land plants: implications for the early evolution of tracheophytes. Bot. Gaz. 152: 335-356.

Kenrick P \& Crane PR. 1997a. The origin and early diversification of land plants: a cladistic study. Smithsonian Series in Comparative Evolutionary Biology. Smithsonian Institution Press, Washington.

Kenrick P \& Crane PR. 1997b. The origin and early evolution of plants on land. Nature 389: 33-39.

Kenrick P \& Edwards D. 1988. The anatomy of Lower Devonian Gosslingia breconensis Heard based on pyritized axes, with some comments on the permineralization process. Bot. J. Linn. Soc. 97: 95-123.

Kenrick P, Edwards D \& Dales RC. 1991. Novel ultrastructure in water-conducting cells of the Lower Devonian plant Sennicaulis hippocrepiformis. Palaeontology 34: 751-766.

Kenrick P, Wellman CH, Schneider H \& Edgecombe GD. 2012. A timeline for terrestrialization: consequences for the carbon cycle in the Palaeozoic. Phil. Trans. Roy. Soc. London B367: $519-536$. 
Labandeira CC. 2005. Invasion of the continents: cyanobacterial crusts to tree-inhabiting arthropods. Trends Ecol. Evol. 20: 253-262.

Lak M, Néraudeau D, Nel A, Cloetens P, Perrichot V, Tafforeau P. 2008. Phase contrast X-ray synchrotron imaging: Opening access to fossil inclusions in opaque amber. Microsc. Microanal. 14: 251-259.

Li CS. 1990. Minarodendron cathaysiense (gen. et comb. nov.), a lycopod from the late Middle Devonian of Yunnan, China. Palaeontograph. B220: 97-117.

Ligrone R \& Duckett JG. 1996. Development of water-conducting cells in the antipodal liverwort Symphyogyna brasiliensis (Metzgeriales). New Phytol. 132: 603-615.

Lucas WJ, Groover A, Lichtenberger R, Furuta K, Yadav S-R, Helariutta Y, He X-Q, Fukuda H, Kang J, Brady SM, Patrick JW, Sperry J, Yoshida A, Ana-Flor Lopez-Millàn A-F, Grusak MA \& Kachroo P. 2013 The plant vascular system: evolution, development and functions. J. Integr. Plant Biol. 55: 294-388.

Meyer-Berthaud B, Soria A \& Decombeix AL. 2010. The land plant cover in the Devonian: a reassessment of the evolution of the tree habit. In: Vecoli M, Clément G \& Meyer-Berthaud B (eds.), The terrestrialization process: modelling complex interactions at the biospheregeosphere interface: 5-70. The Geological Society, London.

Mosbrugger V. 1990. The tree habit in land plants. Lecture Notes in Earth Science 28: 1-161.

Niklas KJ. 1985. The evolution of tracheid diameter in early vascular plants and its implications on the hydraulic conductance of the primary xylem strand. Evolution 39: 1110-1122.

Niklas KJ. 1997. The evolutionary biology of plants. University of Chicago Press, Chicago.

Pittermann J, Sperry JS, Hacke UG, Wheeler JK \& Sikkema EH. 2006. Inter-tracheid pitting and the hydraulic efficiency of conifer wood: the role of tracheid allometry and cavitation protection. Amer. J. Bot. 93: 1265-1273.

Pittermann J. 2010. The evolution of water transport in plants: an integrated approach. Geobiology 8: 112-139.

Rasband WS. 2012. ImageJ. U.S. National Institutes of Health, Bethesda, Maryland, USA. http://imagej.nih.gov/ij/. 1997-2012.

Rothwell GW, Sanders H, Wyatt SE \& Lev-Yadun S. 2008. A fossil record for growth regulation: The role of auxin in wood evolution. Ann. Missouri Bot. Gard. 95: 121-134.

Sperry JS. 2003. Evolution of water transport and xylem structure. Int. J. Plant Sci. 164: S115S127.

Spicer R \& Groover A. 2010. Evolution of development of vascular cambia and secondary growth. New Phytol. 186: 577-592.

Stein WE. 1993. Modeling the evolution of stelar architecture in vascular plants. Int. J. Plant Sci. 154: 229-263.

Stein WE, Berry CM, Hernick LV \& Mannolini F. 2012. Surprisingly complex community discovered in the mid-Devonian fossil forest at Gilboa. Nature 483: 78-81.

Stein WE, Mannolini F, Hernick LV, Landing E \& Berry CM. 2007. Giant cladoxylopsid trees resolve the enigma of the Earth's earliest forest stumps at Gilboa. Nature 446 (7138): 904-907.

Strullu-Derrien C, Ducassou C, Ballèvre M, Dabard MP, Gerrienne P, Lardeux H, Le Hérissé A, Robin C, Steemans P \& Strullu DG. 2010. The early land plants from the Armorican Massif: sedimentological and palynological considerations on age and environment. Geol. Mag. 147: 830-843.

Strullu-Derrien C, Kenrick P, Tafforeau P, Badel E, Cochard H, Bonnemain JL, Le Hérissé A \& Lardeux H. (submitted). The earliest wood and its hydraulic properties documented in 407 million-year-old fossils using synchrotron microtomography.

Tafforeau P \& Smith TM. 2008. Nondestructive imaging of hominoid dental microstructure using phase contrast X-ray synchrotron microtomography. J. Human Evol. 54: 272-278. 
Taylor TN, Taylor EL \& Krings M. 2009. Paleobotany: the biology and evolution of fossil plants. Ed. 2. Elsevier, Academic Press, New York.

Tyree MT \& Zimmermann MH. 2002. Xylem structure and the ascent of sap. Springer, Berlin. Wang DM, Hao SG \& Wang Q. 2003. Tracheid ultrastructure of Hsua deflexa from the Lower Devonian Xujiachong Formation of Yunnan, China. Int. J. Plant Sci. 164: 415-427.

Wilson JP \& Fischer WW. 2011. Hydraulics of Asteroxylon mackei [sic], an early Devonian vascular plant, and the early evolution of water transport tissue in terrestrial plants. Geobiol. 9: $121-130$.

Wilson JP \& Knoll AH. 2010. A physiologically explicit morphospace for tracheid-based water transport in modern and extinct seed plants. Paleobiol. 36: 335-355.

Wilson JP, Knoll AH, Holbrook NM \& Marshall CR. 2008. Modeling fluid flow in Medullosa, an anatomically unusual Carboniferous seed plant. Paleobiol. 34: 472-493.

Accepted: 8 September 2013 